\title{
Walmart's communication techniques for sustaining stakeholder trust: How CEOs answer critics and reassure stakeholders in their annual and CSR report letters
}

\author{
Catherine Resche, University Paris 2 Panthéon-Assas, Foreign language department, CELISO, \\ Sorbonne University, France \\ catherineresche@club-internet.fr
}

\begin{abstract}
Based on a corpus of Walmart CEOs' letters introducing the annual and sustainability reports from 2005 to 2016, this paper investigates the company's communication techniques to limit loss of social and symbolic capital in order to bolster up morale and retain or attract investors in a period of repeated crises and attacks from a number of critics. Analysis of the corpus evidences a careful selection of the themes addressed year after year, the rule being for CEOs to choose when to react, and what to leave out. Answers to critics remain subtle and indirect, and the resources of rhetoric are fully exploited through metadiscourse and counter narrative to insist on the company's strengths, celebrate its heroes and to highlight its enduring values. Renewal discourse is meant to offer a new vision for the company and reassure investors and other stakeholders.
\end{abstract}

\section{Keywords}

Walmart, CEO annual letters, crisis communication, rhetoric, renewal discourse

\section{Introduction}

This paper purposefully focuses on Walmart, a company with an impressive financial track record that imposed itself as the twentieth-century leading retailer and the world's tenth biggest economic entity. The point is to study the communicative techniques used by the company to sustain trust in the twenty-first century's highly-challenging context. Although Walmart has topped the Fortune Global 500 list for over two decades, posting a \$ 500-billion revenue in 2017, its has realised how important it is to reinvent itself if it is to compete with today's asset-light companies like Amazon. The more successful a company is, the greater the challenge for it to preserve its rank, to maintain its financial health, and to persuade its shareholders and other stakeholders to keep trusting in its ability to endure as a leader. Probably because of its very reach and size, the US retail giant has long been targeted by opponents and critics and has suffered a series of attacks. A company's economic capital can be at risk if its social capital (trust) and its symbolic capital (im- age and reputation) are damaged (Frandsen \& Johansen, 2017, p. 10).

Although companies can now resort to a variety of tools and website pages to communicate with their numerous stakeholders, CEO annual letters (ALs), where "tone at the top" is conveyed (Amernic, Craig, \& Tourish 2010, p. 1), still have "enormous rhetorical importance in building credibility and imparting confidence" (Hyland, 1998, p. 224). This paper therefore draws on a corpus of Walmart CEOs' ALs and SLs (letters introducing the sustainability/global responsibility reports) over a twelve-year period (20052016). The point is to analyse how Walmart CEOs have adapted their communication strategy to deal with various crises and problems threatening the company's identity and image, and with the growing array of activists ${ }^{1}$ whose attacks might hurt and affect its financial health. More precisely, the paper focuses on the rhetorical, struc-

1 In addition to the United Food and Commercial Workers International Union, Wakeupwalmart, a large-budget, anti-Walmart lobbying group in Washington, has been actively trying to influence politicians. 
tural, stylistic, narrative and lexical devices CEOs rely on to control or repair the damage done to their company's brand image, and maintain or restore stakeholder trust (Conley, 2015).

The year 2005 was deemed a logical starting point for this investigation as it marked a turning point in three main respects. Firstly, it saw the release of two documentary films about the company on the same day: a very critical, union-endorsed one (Greenwal, 2005) and an independent one (Galloway \& Galloway, 2005). Both films make emotive-ethical appeals (Boje, 2008) and confirm the idea that as many good stories as bad stories could be written about the corporate giant. Understandably, the company decided to react to the negative narrative that risked poisoning its brand, and affecting stakeholder trust. Secondly, 2005 was the year when Walmart created a public relation 'war room' to respond to mounting criticism, as well as a new position for a chief marketing officer (CMO). And, thirdly, it also released an important declaration (Scott, 2005), followed by its first-ever global responsibility report. ${ }^{2}$ The year 2016, which ends the period under review in this paper, was marked by unsettling news: For the first time in its history, Walmart announced that it expected sales to be flat in 2017, and that it was to close 269 stores globally, allegedly to make "strategic investments" likely to support the "long-term health of the company" (AL 2016).

The diachronic approach underpinning this analysis aims at assessing the changes that have taken place in the CEOs' communication techniques in response to the series of crises and reputational threats that the company has had to face since 2005. Part one offers a brief overview of the theoretical frame for this research. Part two outlines the method adopted and

2 As a matter of fact, the name of the reports has varied over time: in 2007-2008, it was "Sustainability progress", and it was changed into "Global responsibility report" in 2009, only to revert to "Sustainability report" in 2010, and finally stabilize as "Global responsibility report" today. part three focuses on the results, which are discussed further in part four.

\section{Theoretical frame}

The theoretical frame which served as a basis for this research borrows from crisis and reputational management theory, on the one hand, and from genre and discourse analysis on the other hand, especially as regards authority and persuasion.

Among the eight categories of crises identified by Lerbinger (1997), four seem to have affected Walmart in some way during the period under review: natural disaster, with the 2005 Katrina hurricane, confrontation crises leading to boycotts, flash mobs, and sit-ins, and crises linked with rumors of organisational misdeeds. Crises are more difficult to manage today when the viral effect of social networks can be devastating and when traditional public-relations tools are rendered less effective in addressing reputational challenges. McKinsey researchers also mention "the increasing significance of non-governmental organisations (NGOs) and other third parties, and declining trust in advertising" (Bonini, Court, \& Marchi, 2009). Thus, companies need to develop the right social media-monitoring tools to detect early signs of a crisis and to assess the impact of such news on stakeholder sentiment.

Impression management, i.e. "the goal-directed activity of controlling information in order to influence the impressions formed by an audience" (Schlenker, 1980) of a person, a group or an event, is a familiar notion for companies that have become conscious of the need to anticipate stakeholders' reactions to any crisis and to the crisis response strategies they devise (Coombs, 2007). Leary and Kowalski (1990, p. 37) point out that "conveying the right impression increases the likelihood that one will obtain desired outcomes and avoid undesired outcomes" and they insist on self-presentation and its motivations. CEO letters do include portions of self-presentation that need to be analysed in this light. For observers, being able to identify the techniques used, and the choices made 
by companies to manage stakeholder sentiment can also help detect "the potential deception inherent in such practices" (Brennan \& Merkl-Davies, 2013, p. 109).

Image repair discourse (Benoit, 1997; Austin, Liu, \& Jin, 2014), which is based on persuasion and the ability to adapt one's arguments to one's audience, should combine accepting responsibility and 'bolstering, i.e., focusing on the positive aspects, reminding the public of past successes and insisting on achievements.

It is a widely-accepted fact among researchers who have studied the AL genre (Hyland, 1998; Jameson, 2000; Amernic et al., 2010; Resche, 2010; Dragsted, 2014) that CEOs seek to convey a positive image of their companies. As well as the annual reports they introduce, ALs and SLs have become public relation documents addressing all stakeholders, including society at large (Laskin, 2009; Lischinsky, 2011). Whatever the themes addressed, which depend on the issues at stake, positive words are given priority, regardless of performance (Rutherford, 2005). CEOs do have a rhetorical purpose: They mean to "gain the reader's acceptance for the particular definition of reality" they choose to provide in their letters, and metadiscourse helps them establish their credibility and legitimacy (Hyland, 1998, p. 233): first-person pronouns are frequent in good years, contributing to their own positive image. It has been established that CEO discourse remains the best means for conveying the company's shared set of values (Cunningham, 2014) and for explicitly reasserting "adherence to high moral principles or professional standards" (Amernic et al., 2010, p. 7).

The theoretical framework which has just been sketched brings evidence that the letter to the shareholders is used by the CEO as a promotional tool to present his view and interpretation of the events and highlight the data he has carefully selected. So, even though it partly reports on quantitative data, the document is largely subjective. Accordingly, the corpus was analysed with a view to identifying the strategic choices made by Walmart's CEOs to make the most out of their communication skills to control damage, contain potential loss of trust, uphold or restore the company's reputation and react to opponents' criticism and attacks. The ultimate goal is to convince observers and experts that Walmart is still a safe-haven investment.

\section{Method and background}

The 31167-word corpus, which spans a twelve-year period (2005-2016), was gathered from the company's website and includes both ALs (annual letters) and SLs (letters introducing the sustainability/global responsibility reports) by Walmart CEOs. A secondary corpus, built and retrieved from the Making Change at Walmart website ${ }^{3}$ (MCAW) - formerly Walmart Watch - was compiled in order to better assess the extent of the attacks against Walmart, dubbed "Woe-Mart" by its critics, and to identify the worst years for the company's reputation. This secondary website, which is run by the United Food and Commercial Workers International Union ${ }^{4}$ (UFCW), is fed regularly with systematically very aggressive posts, all the more so as Walmart has so far managed to prevent its "associates", as its employees are called, ${ }^{5}$ from joining unions. As CEO discourse does not exist in a vacuum, the point was to look for echoes of, and answers to the MCAW attacks ${ }^{6}$ in the CEO letters, and to analyse the CEOs' tactics for countering their critics' arguments.

3 MCAW is described as the national campaign to change Walmart into a more responsible employer.

4 The UFCW also sponsors and partly funds a labour group called OUR Walmart (Organisation United for Respect at Walmart), which is dedicated to persuading Walmart to pay its employees $\$ 13$ an hour. Actually, the organisation is listed as a subsidiary of UFCW in papers filed with the US Department.

5 Walmart changed the word 'employees' into 'associates' in 1973.

6 Actually, the MCAW website often borrows criticism from a multivocal arena that is not restricted to activist groups, but is also composed of customers, employees, trade associations, and commentators. 
In this respect, the year 2005 marked a turning point in Walmart's communication strategy insofar as the company decided to counterattack by telling its own story itself, highlighting progress on the very human and social issues that Walmart's critics had pointed out as weaknesses or failures:

For me personally, you can expect to see me continue to tell the Walmart story more aggressively. [...] We have such a good story to tell at Walmart, from the career opportunities we're creating, the support we provide to individual communities, and the improved standard of living we're providing to our customers through our low prices and wide assortment. $(\mathrm{AL} 2005)^{7}$

As Gabriel (2004) underlined, part of the process of sense-making consists for CEOs in choosing to frame or reframe the reality and influence the perception of the stakeholders. Special attention was therefore paid to how Walmart's CEOs managed to offer a different narrative, what their strategy was based on, whether they chose to counter-attack immediately or to defer their answers, to mention the problems directly or indirectly, to deflect responsibility to other stakeholders, or to divert the public's attention by highlighting positive news, thus leaving the damageable elements in the shadows. Silences are also meaningful as a strategy. During the decade under review, 2012 seems to have been Walmart's annus horribilis. That year, a fire broke out in the Tazreen garment factory near Dhaka in Bangladesh, where more than 200 workers were injured and 117 died. Walmart was identified as one of the brands related to the local subcontractor. In addition, allegations of corruption involving high-level Walmart executives in Mexico were made public (Barstow, 2012). ${ }^{8}$ The company was said to have paid bribes to obtain permits to build stores in virtu-

7 Italicised words in all quotations are to be understood as emphasis added by the author of this paper.

8 The scandal was exposed when David Barstow's article was printed in the New York Times and posted online. ally every corner of the country. Instead of applying the now well-known crisis management mantra "Tell it Early, Tell it All, Tell it Yourself” (Davis, 1999), Walmart's management was alleged to have covered up the problem, which caused the company to lose some of the reputational capital it had acquired over time. Reputational capital, as defined by Fombrun and Van Riel (2004, p. 32) is an organisation's “stock of perceptual and social assets - the quality of the relationship it has established with stakeholders and the regard in which the company and brand is held". Preserving such a "reservoir of goodwill" (Ulmer, Sellnow, \& Seeger, 2018) strengthens the company's resilience in bad times.

The method used for analysing the CEO letters combines bottom-up and topdown approaches. The first step consisted in reading the letters very closely, with a view to gathering qualitative information on the elements likely to provide clues as to the strategy adopted by the CEOs to reassure investors and restore stakeholder trust: themes, metaphors, recurring phrases, value-laden words, co-occurring words, rhetorical patterns, broken patterns, ethos building and metadiscursive techniques, etc. Metaphors are often embedded in the deep structure of the text rather than stated overtly, which required conducting forensic examination of the letters. The second step consisted in supplementing the qualitative approach using Antconc, a text analysis software tool ${ }^{9}$ to retrieve quantitative data from the corpus.

\section{Results}

The following sub-sections highlight a number of techniques used by Walmart's CEOs to adapt the length and structure of their letters to the challenges faced by the company (4.1). Their strategic response to direct attacks consists in deciding when

9 AntConc is a freeware corpus analysis toolkit for concordancing and text analysis developed by Laurence Anthony at Tokyo's Waseda University. The version used here is AntConc 3.5.0 (2015). It is available from https://www.laurenceanthony.net/. 
Table 1: Length of ALs and SLs

\begin{tabular}{|c|c|c|c|}
\hline Year & Name of the CEO & AL (average length $=1266$ words) & SL \\
\hline 2005 & Lee Scott & 1161 & 4817 \\
\hline 2006 & $"$ & 978 & 309 \\
\hline 2007 & $"$ & 1627 & $2007-2008^{\mathrm{a}}$ \\
\hline 2008 & $"$ & 1090 & \\
\hline 2009 & Michael T. Duke & 1240 & 1750 \\
\hline 2010 & $"$ & 1130 & 1424 \\
\hline 2011 & $"$ & 1061 & 1212 \\
\hline 2012 & $"$ & 1604 & 1493 \\
\hline 2013 & $"$ & 501 & 312 \\
\hline 2014 & Doug McMillon & 1590 & 448 \\
\hline 2015 & " & 1295 (+ a 631-word Q \& A passage & 575 \\
\hline 2016 & $"$ & 1395 & $\begin{array}{c}644 \text { (+a 495-word letter by the chief } \\
\text { sustainability officer) }\end{array}$ \\
\hline
\end{tabular}

and how to answer and when to remain silent (4.2). They also resort to the Aristotelian triad (4.3) to maintain trust, to guide their audience's understanding of events and decisions, to persuade their public that the company's original values still endure and to tell a convincing story by using metaphor as an argumentative framing strategy.

\subsection{Length and structure}

Kohut and Segars' remark (1992) about bad news being expressed using fewer words seems to verify in the corpus. As shown in Table 1, the shortest ALs happen to be those of 2006 (978 words) and 2013 (501 words), following two difficult years (2005 and 2012) as far as attacks or scandals are concerned.

SLs vary much more length-wise: The 2005 founding text for the $21^{\text {st }}$ century was exceptionally long (4817 words) as it reviewed all the aspects of Walmart's CSR program and thus indirectly answered many of the criticism leveled at the company. It can be read as the company's pledge to change and improve its ways, taking into consideration the remarks and advice from a number of groups outside Walmart. Also to be noted is the choice to combine the years 2007 and 2008 into a much longer letter than the following ones: As the program was then gradually implemented between 2008 and 2012, SLs became shorter, until they reached about 500 words on average.
In 2016, a new job was created for a chief sustainability officer, whose letter accompanied that of the CEO.

The structure of ALs varies slightly: most of them are divided into 4 to 7 sub-parts with intermediate headings to guide the reader. Yet, again, the 2006 and 2013 letters stand in sharp contrast with the usual structure. The 2006 letter has a very sober structure with no intermediate headings and its title - "Building smiles today and tomorrow" - is meant to divert attention from the recent difficulties. The untitled 2013 letter has only one intermediate heading: "Financial results and key strategies". The selection of intermediate headings in Table 2 deserves special attention: through them, CEOs choose to draw attention to specific problems, address particular stakeholder groups, and tackle issues denounced by critics, such as wages, discrimination, or lack of consideration for communities, suppliers, and the environment. The message is also meant to reassure investors as to the company's ability to lead and win, embrace challenges and adapt to a changing world.

As for patterns, unsurprisingly, all letters begin and end on positive notes, either praising associates, reasserting foundational values and beliefs, reminding the reader of the company's vision, or expressing optimism as regards the future. Financial results in ALs are announced early in the text, mostly in the first or second para- 
Table 2: Insightful intermediate headings in CEOs' letters introducing annual and sustainability reports

\begin{tabular}{|c|c|c|}
\hline Year & ALs & SLs \\
\hline 2005 & $\begin{array}{l}\text { Outstanding growth prospects } \\
\text { Associates will take us to the next level }\end{array}$ & Waste/Product sourcing/Wages/Communities/Diversity \\
\hline 2007 & $\begin{array}{l}\text { Customer relevancy } \\
\text { Taking care of associates } \\
\text { Valuable to communities }\end{array}$ & - \\
\hline 2008 & $\begin{array}{l}\text { Making a difference } \\
\text { Better positioned }\end{array}$ & - \\
\hline 2009 & Job creation and advancement & Caring about our communities \\
\hline 2010 & This time and this world & Responsible sourcing \\
\hline 2011 & Leading on social issues & We recognize that leadership brings higher expectations \\
\hline 2012 & $\begin{array}{l}\text { Reinvigorating our customer-focused culture } \\
\text { Leading on social and environmental issues } \\
\text { Looking ahead }\end{array}$ & - \\
\hline 2014 & $\begin{array}{l}\text { Earning trust in communities } \\
\text { Embracing the challenge to change }\end{array}$ & - \\
\hline 2015 & $\begin{array}{l}\text { Investing in customer relevance } \\
\text { Engaged associates fuel our success } \\
\text { Committed to a better world }\end{array}$ & - \\
\hline 2016 & $\begin{array}{l}\text { Our plan to win is clear } \\
\text { We made great progress } \\
\text { We will win with a differentiated, disruptive strategy }\end{array}$ & - \\
\hline
\end{tabular}

Note: The sign - means that there were no intermediate headings for the corresponding years.

graphs, except for 2014, where details of "solid performance in a challenging world" are mentioned in the ninth paragraph, a sign that the changing, adverse context is being felt more acutely. Evaluative adjectives should be compared year after year: they vary from "outstanding" growth prospects in "record" (2005) or "extraordinary" years to "robust" growth, "strong" earnings (2008) or returns (2009), and "really good" (2013) or simply "solid" performance (2014) in more difficult times. Some of the less enthusiastic adjectives are used in contexts such as a "challenging" and "competitive" environment (2014), a "difficult" economy, or "a period of disruption" and "stiff competition" (2016). The relatively less positive evaluative adjectives are softened by encouraging phrases like "we have a lot to be proud of" (2006) or "we are pleased", but they may also be used in conjunction with comments related to "a couple of disappointments" (2007) or "higher expectations" (2015).

As a rule, Walmart's strategy consists in keeping control over when and how it will react to criticism, and what it will leave out.

\subsection{Silences and indirect answers}

The main silences concern the Mexico scandal - also known as "Mexigate" - and the Bangladesh tragedy, which are never mentioned as such in the letters; neither are the numerous lawsuits. Systematically, the company prefers to choose when to react, perhaps to give the impression that the changes announced are guided by its overall philosophy, and part of a broader plan, rather than letting pressure groups dictate their own schedule. The CEO's silence about the 2012 Bangladesh accident may also be a sign of embarrassment, especially as Walmart had proclaimed its commitment to greater vigilance about supplier factory conditions as early as 2005 in its $21^{\text {st }}$ century leadership text:

We have certainly made progress in helping our suppliers, whose factories make goods for our stores, support their workers by treating them properly, wherever they are located. In fact, we cease doing business with supplier factories if they fail to meet our ethical standards. But there is more we can do in this area. We are committed to further increasing our engagement concerning supplier factory con- 
Table 3: Common complaints and attacks, and Walmart's indirect answers

\begin{tabular}{|c|c|}
\hline Complaints and attacks & Walmart's indirect answers \\
\hline $\begin{array}{l}\text { Opposition to store openings in } \\
\text { some communities and big cities }\end{array}$ & $\begin{array}{l}\text { As part of this growth, we are making a concerted effort to work more collaboratively with our commu- } \\
\text { nities. This includes being more flexible with city leaders on our individual store designs, and making } \\
\text { sure we are a good local citizen as we open new stores. (AL 2005) }\end{array}$ \\
\hline $\begin{array}{l}\text { Germany's resistance to Walmart's } \\
\text { model and anti-union policy }\end{array}$ & $\begin{array}{l}\text { Exiting Germany and South Korea last year was the right decision, and we have redeployed resources } \\
\text { from those countries to other critical areas of our International division. (AL 2007) }\end{array}$ \\
\hline Poor job conditions & $\begin{array}{l}{[\ldots] \text { in February, we announced a } \$ 1 \text { billion investment in our U. S. hourly associates to provide higher }} \\
\text { wages, more training and increased opportunities to build a career with Walmart. (AL 2015) }\end{array}$ \\
\hline Job discrimination & $\begin{array}{l}\text { As the world's largest private employer, Walmart has the responsibility to lead in important areas such } \\
\text { as diversity. [...] Regardless of race, gender or where you live, each associate has the opportunity to } \\
\text { grow and succeed at Walmart. (AL 2008) }\end{array}$ \\
\hline Lack of career opportunities & $\begin{array}{l}\text { [...] we promoted about } 190000 \text { U. S. store and club associates last year to jobs with more responsibil- } \\
\text { ity and higher pay. And, we'll continue to invest in training and development because building the best } \\
\text { team in retail is central to our strategy. (AL 2014) }\end{array}$ \\
\hline Integrity questioned & $\begin{array}{l}\text { [... integrity is rooted in our decisions and our culture. (AL 2012) } \\
\text { We are deeply committed to compliance and social, environmental and local responsibility. Operating } \\
\text { with integrity is a cornerstone for building trust. [...] Our training and leadership development programs } \\
\text { reinforce the mission of upholding the highest standards of integrity, not just in retail, but in all of } \\
\text { business. (AL 2014) }\end{array}$ \\
\hline $\begin{array}{l}\text { Problems with selection } \\
\text { of suppliers }\end{array}$ & $\begin{array}{l}\text { Last year, I stood in front of more than 1,000 suppliers in Beijing, China and committed our Company } \\
\text { to building a more socially and environmentally responsible supply chain. We'll make a difference in } \\
\text { responsible sourcing that no other retailer and no other company can make. (AL 2009) }\end{array}$ \\
\hline $\begin{array}{l}\text { Problems with stocks and choice } \\
\text { in stores }\end{array}$ & $\begin{array}{l}\text { The Walmart U. S. team is implementing a broad range of initiatives focused on strengthening our } \\
\text { assortment (especially the fresh offering), driving the integration of e-commerce with our stores, and } \\
\text { improving the customer experience. (AL 2015) }\end{array}$ \\
\hline
\end{tabular}

ditions and becoming more transparent in this important area. (AL 2005) of our critics then are some of our best advisors now. (SL 2014)
As evidenced through a selection of Walmart's indirect answers to common complaints in Table 3, Walmart's communication strategy consists in responding in a subtle manner when accused of wrongdoing.

The company does not ignore critics, however. Positive collaboration with NGOs, environmentalists, and other groups is highlighted. Actually, Walmart's CEOs insist on the company's ability to listen to criticism as long as it is constructive and can help the company to improve, which suggests that any attempt at systematic bashing is disregarded:

We started asking ourselves: What if we needed to change? What if we started listening to NGOs and even our critics more closely? [...] At first, there were some awkward conversations - frank meetings with folks we had never met with before. But what came out of those conversations was exhilarating. In fact, some
Listening and learning, then acting and improving, such is the indirect answer to attacks and a means to convince the public that management is able to admit its shortcomings, and express concern, as expected by stakeholders and recommended by crisis experts. As the latter insist, however, expressions of concern are not admissions of guilt (Fuchs-Burnett, 2002; Patel \& Reinsch, 2003).

\subsection{Use of rhetoric}

Walmart's strategy to maintain or restore trust is based on three main rhetorical devices that are used in most letters and are inter-related. The first one concerns ethos-building through metadiscourse. The second one relies on a series of strategic arguments aiming at reasserting the values of the company, linking past and present through regular mentions of, and quotations from Sam Walton, its founder turned hero. The narrative thread is further exploited through the third device 
Table 4: $\quad$ 0ccurrences of "I", "me" and "my" in each letter every year

\begin{tabular}{lccr}
\hline Year & Total & Year & Total \\
\hline 2005 & 48 & 2011 & 19 \\
2006 & 1 & 2012 & 16 \\
2007 & 7 & 2013 & 6 \\
2008 & 10 & 2014 & 25 \\
2009 & 37 & 2015 & 12 \\
2010 & 31 & 2016 & 0 \\
\hline
\end{tabular}

that consists in offering a metaphorical frame picturing the company as a pioneer on a long and difficult journey, and in imparting the company's vision and role.

\subsubsection{Ethos-building and metadiscourse}

Credibility is essential if trust is to be gained or restored, and the CEO's image is often conveyed through the use of first-person subject or object pronouns, as well as possessive adjectives. Through these instances of metadiscourse, the CEO can disclose personal data, express personal comments about the company, its actions, and its people, or share his optimism with the public. Although first-person pronouns can appear in different parts of the letter, they are mostly to be found either in the introductory or ending paragraphs, which are known to set the tone. As Table 4 evidences, the years when such metadiscourse is more frequent are also years with good results, when it is easier for the CEO to come forward.

A quantitative approach, however, is not as meaningful as a qualitative one here. Actually, more insight can be gained by focusing on the verbs used with "I" in the corpus, which mostly express positive personal opinions and feelings likely to encourage "associates" to do their best, and to assure other stakeholders of the CEO's personal involvement in the company's success, as evidenced by Table 5 :

The most frequently used verbs (highlighted in table 5) are those that enable the CEOs to impart their pledge to act (will), to serve the company and its stakeholders, and to insist on continuity. The verb "believe" also helps reinforce the CEOs' influence; surely their statements and hopes
Table 5: Verbs with "I", and adjectives with "I am"

\begin{tabular}{|c|c|}
\hline I+VERB & $\begin{array}{l}\text { appreciate (8), believe (38), continue (72), } \\
\text { feel (5), hope (14), intend (2), know (17), learn (7), } \\
\text { love (3), mean (2), pledge (1), recognize (6), } \\
\text { see (7), serve (45), share (13), thank (3), } \\
\text { want to (2) }\end{array}$ \\
\hline I will & (63) \\
\hline $\begin{array}{l}\text { I am / I'm } \\
\text { (31)+adjectives }\end{array}$ & $\begin{array}{l}\text { confident, encouraged, excited, fortunate, } \\
\text { impressed, optimistic, pleased, proud }\end{array}$ \\
\hline
\end{tabular}

are worth taking into account, considering they have privileged information. The company's "associates" will also be sensitive to their CEOs' ability to "appreciate" their efforts and stakeholders will be reassured to read that CEOs are able to "recognize" problems and "learn" from mistakes. It is also worth mentioning that the adjectives associated with "I am" in the corpus are all very positive, especially as they are used in conjunction with evaluative adverbials such as "continually", "especially", "really", or "very", serving as boosters.

First-person pronouns also help CEOs shorten the distance between management and "associates" by providing personal accounts of their own paths within the company, thus bearing testimony to what can be achieved through hard work and commitment, and reminding stakeholders of the basic principles guiding the company. With such success stories, which cannot leave anyone indifferent, CEOs rely on ethos and pathos to reach a large public, arouse admiration and inspire loyalty:

I first started working for Walmart 30 years ago when I was a teenager. I've fallen in love with our company, its people, our purpose and culture. We have a unique culture grounded on four basic beliefs: service to our customers, respect for the individual, striving for excellence and acting with integrity. As CEO, I want to continue to nourish and strengthen these foundational beliefs. (AL 2014)

Walmart has always provided a ladder of opportunity - one that today is available to our 2.2 million associates globally. [...] I am one of many leaders in our company who benefited from this opportunity to begin as an hourly 
associate and grow into roles with increased responsibility. (AL 2015)

Obviously, associates reading the last sentence of the 2015 extract will conclude that the same path can logically open before them, provided they do their best to prove their worth.

When the context is more challenging, however, the CEO's presence is less obvious and the grammatical pattern known as subject extraposition or introductory it will be preferred, as in "it is essential / important / critical that / to". It nevertheless affords the CEO the opportunity to influence his public to see the situation in the same way as himself.

Lastly, while CEOs prefer using the "I" pronoun to congratulate and thank their associates personally, they do not hesitate to distinguish between "I'm pleased" and "We are not satisfied", often using the two forms in the same sentences, as if to soften the message that more efforts and better results are expected: "Though we are never satisfied, I am pleased with our progress over the past year" (AL 2012).

\subsubsection{Linking past and present: Highlighting the company's enduring values}

Another technique for reassuring stakeholders, reasserting the company's values, and also answering concerns raised by activists, consists in letting the company's late founder enjoy a posthumous presence in the letters: Although he died in 1992, Sam Walton is mentioned 42 times in the corpus, either through direct quotes, or through indirect references (Table 6).

A well-known, respected pioneer, a courageous change initiator, and a man of principles, Sam Walton is called upon by CEOs, in a sort of Bakhtinian double narration (Boje \& Rosile, 2007, p. 2), to reassure the public that the rules he set are still played by. The ensuing polyphonic effect is meant to legitimise the current CEOs' authority; the founder would certainly approve of the way today's CEOs carry on the same mission he set for himself, and would support the decisions they make in order to adapt to the new challenges:

\begin{abstract}
More than 40 years ago, our founder Sam Walton understood people needed to save money so they could live better. [...] We work hard every day in all our markets to deliver on this promise. We operate with the same level of integrity and respect that Mr. Sam put in place. (AL 2009)
\end{abstract}

Doing what is right is mandatory at all levels, and integrity is rooted in our decisions and our culture. Sam Walton understood the link between integrity and reputation. (AL 2012)

Year after year, the numerous references to the spectral icon feed the legend, and ensure cohesion through intertextuality. The carefully selected quotes also provide a positive counter-narrative. For example, the year 2012, though a difficult year, also marked Walmart's $50^{\text {th }}$ anniversary, which was a welcome opportunity to celebrate, highlight the company's values and extol its accomplishments:

\begin{abstract}
Fifty years ago, there was a single Walmart discount store. Today, there are thousands of stores, millions of associates and hundreds of millions of customers shopping every week As I travel around the world, it is always inspiring to see the images and words of Sam Walton in our stores. One quote of Sam's that I really like is this: "I had no vision of the scope of what I would start ... but I always had confidence that as long as we did our work well and were good to our customers, there would be no limit to us." (AL 2012)
\end{abstract}

Walmart's CEOs probably count on the company's past reputation and success to act as "a buffer" against lost reputational capital (Coombs, 2007) and to enable it to restore its reputation more quickly. The 2012 reference to Sam Walton's vision also suggests that there is no fundamental contradiction between the company's global reach and the founder's initial philosophy and values, which counters anti-Walmart activists' anti-globalisation stance. The 
pioneering spirit of the founder, and his challenge-embracing character, help to present international expansion as a logical evolution and as progress.

\subsubsection{Staging the story through a metaphorical frame}

When Walmart announced its determination to tell its own story "aggressively" in its 2005 letter, the adverb was not to be taken literally: CEOs never attack their opponents headfirst, but aim at setting the record straight in more subtle ways. For example, the opponents' negative image of Walmart as "the Beast of Bentonville" is fought against by foregrounding the company as "the Lighthouse of the Ozarks", a quote borrowed from the company's founder:

I'd like to believe that as Walmart continues to thrive and grow, it can come to live up to what someone once called us: The Lighthouse of the Ozarks. Only I hope we can spread the concept further than our home region here in the foothills. We have to study more ways we can give back to our communities. We're already studying ways to be more socially conscious all around. (AL 2011)

The Lighthouse metaphor is appropriately revived to convey the idea of a company that serves as a reference, a company that is visible to all, and conscious of its mission to guide and protect people. The idea of spreading Walmart's influence more widely, of serving more people, while remaining true to its values and culture, finds many echoes in the letters. CEOs describe their responsibility as leading the company on "a journey" (AL 2006), "out in front" (AL 2007) and "on the move" (SL 2015):

You know, as I close, I hope you have a sense that this is a company on the move and, like Sam Walton, we are going to have the courage to lead and do what is right. Whether the environment, product sourcing, healthcare and wages, community involvement or diversity, we are investing in the future. We have an aggressive vision. With courage and commitment to change, we will be at our best and re- main true to the legacy of the company Sam Walton founded some 43 years ago. (SL 2015)

CEOs are "committed to this journey"; they are aware that they "still have a long way to go in many areas" and that they "are going to hit unexpected bumps along the way" (2012). Still, they "have made steps toward becoming a more sustainable, responsible company and building meaningful, longterm change" (2012).

The metaphor of the long journey ahead enables them to acknowledge the difficulties and failures, but also to convince stakeholders that they are determined to take up the challenge and carry on their mission. To this end, they readily use the adverb "aggressively", which cooccurs with implementing "sustainable business practices", "investing in technology and innovation", pursuing "regulatory and policy changes", "reducing emissions" or "rethinking merchandising". They also announce "aggressive goals" in terms of building a more environmentally and socially responsible supply chain.

"Rekindling the spirit of innovation that Walmart has been known for throughout [its] history" (2012) is an appropriate goal when the company is faced with challenges: It is a means to reconcile past and present, continuity and the need for change in order to adapt to the new context and prepare for the future. The pioneering spirit is also repeatedly expressed by CEOs in statements such as "change is embedded in our DNA" (AL 2014) or "It is rooted in our culture to stay out in front of change" (AL 2012).

Every opportunity to arouse feelings of admiration for - as well as pride and confidence in - the company is seized by CEOs, as was the case in the $2005 \mathrm{AL}$, when the CEO offered a very personal account of the company's role after Hurricane Katrina. Through his epic description presenting some of Walmart's associates as heroes, he expressed his own recognition and sympathy, and meant to arouse the public's admiration: 
Table 6: A selection of CEOs' mentions of the company's founder

Direct quotes
(2006) On March 17, 1992, the President of the United States present-
ed our founder, Sam Walton, with the Medal of Freedom [...]. Accept-
ing the award, Mr. Sam said: "We'll lower the cost of living for every-
one, not just in America, but we'll give the world an opportunity to see
what it's like to save and do better." Sam Walton saw then what we're
making a reality today at Walmart. And to borrow just a few more of
his words from that moving day: "We think we've just begun."

(2012) We recognize that leadership brings higher expectations, and we embrace the challenge. As Sam Walton said, "High expectations are the key to everything."
References to Sam Walton

(2008) From the day that Sam Walton opened the doors of the first Walmart store in 1962, our mission has been to save people money so they can live better. Today that mission extends to sustainability.

(2010) At Walmart, we are never satisfied because our founder Sam Walton was never satisfied.

(2014) Change is nothing new for Walmart - it's embedded in our DNA.

After all, our company founder, Sam Walton, was the premier innovator in retail. He made Walmart better by questioning everything, every day - frequently asking customers and our store associates how we could do better. [...] the imperative that will guide our transformational initiatives is the same to connect more effectively with customers.

(2015) During Katrina, I was reminded of the vision and innovation of Sam Walton. We became who we are by serving the underserved.
Katrina was a key personal moment for me. When Katrina hit last month, the world saw pictures of great suffering and misery. At Walmart, we didn't watch it, we experienced it. Some of our stores and clubs were under water. Associates lost their savings, their homes, and in a few cases, their lives. I spent time with a few of them in the Houston Astrodome. I saw the pain, the difficulty, and the tears. But I saw something else. I saw a company utilize its people resources and scale to make a big and positive difference in people's lives. I saw how Jessica Lewis, the co-manager of our Waveland, Mississippi store, worked to help those in her community. [...] She didn't call the Home Office and ask permission. She just did the right thing. Just like thousands of our associates who also did the right thing, a trait I am proud to say is bred in our culture. During this time, we were asked by governments, relief agencies and communities to help. And look what happened. We were showered with gratitude, kindness, and acknowledgments. This was Walmart at its best.

Authority and influence are also exerted by engaging with the public through rhetorical questions which can only be given obvious answers as in the following excerpt:
Katrina asked this critical question, and I want to ask it of you: What would it take for Walmart to be that company, at our best, all the time? What if we used our size and resources to make this country and this earth an even better place for all of us: customers, associates, our children, and generations unborn? What would that mean? Could we do it? Is this consistent with our business model? What if the very things that many people criticize us for - our size and reach - became a trusted friend and ally to all, just as it did in Katrina? (AL 2005)

Surely, the company is able to do its best, improve, and overcome obstacles. In its role as a guide, as a "lighthouse", Walmart is endowed with a mission to help people choose the right path, throwing light on areas that are left in the shadows; given its size and weight, it seems to be destined to become a trail-blazer, particularly in issues that have caused it to be targeted by opponents, and to bring solutions in areas where governments fail to act:

It is important for a company like Walmart to step up to make a difference in our communities. Even if governments can't or won't address key issues, it is critical for corporations to take 
the lead. Our associates and our customers expect nothing less. [...] As the world's largest private employer, Walmart has the responsibility to lead in important areas such as diversity. Our teams must reflect the communities we serve. Our associates deserve to succeed as far as their hard work and skills can take them. (AL 2008)

The repeated efforts to amend Walmart's ways are supported by CEO discourse and the theme of renewal: The company has undertaken a journey towards being a better employer, a better and a more responsible corporate citizen. Its positive evolution is conveyed through value-laden phrases such as "re-imagining Walmart", an invitation to hope for a better world where large companies would use their reach to have a positive impact on their human and natural environment. Walmart's ability to look ahead is also highlighted by other catch phrases like " $21^{\text {st }}$ century leadership", "sustainability $360^{\circ}$ ", "sustainable sustainability", or "the next generation Walmart".

\section{Discussion}

In his 2016 letter, the present CEO, Doug McMillon, made a point of announcing "a dividend increase to $\$ 2.00$ per share, marking the 43rd consecutive year of dividend increases for Walmart". Still, although Walmart remains a profitable company, it has gone through difficult times. In 2005, inventories rose even faster than sales, a sign that some stores were mismanaged, and customers dissatisfied. The same year, the CEO insisted on society's changing expectations, and on the challenges involved in entering the $21^{\text {st }}$ century:

You know, we are in uncharted territory as a business. [...] People expect a lot of us, and they have a right to. Due to our size and scope, we are uniquely positioned to have great success and impact in the world, perhaps like no company before us. After a year of listening, the time has come to speak, to better define who we are in the world, and what leadership means for Walmart in the $21^{\text {st }}$ century. (2005 CEO letter highlighting the sustainability plan)

In 2006, the company's “U.S. division eked out a $1.9 \%$ gain in same-store sales - its worst performance ever" (Bianco, 2007). Between 2010 and 2011, Walmart experienced eight quarters of negative growth, a sign that it had lost momentum. In November 2015, its stock hit bottom: It was no longer acknowledged as a growth company by some Wall Street analysts. Walmart has now lost its $n^{\circ} 1$ retailer status to Amazon and is actively trying to catch up by focusing on e-commerce to be more competitive.

Do these problems reflect the inevitable midlife crisis that such a large company can experience? Are they due to its inability to react quickly enough to the new challenges? Was Walmart's strategy in dealing with its reputational problems and the new challenges inadequate? Is the retail giant the problem or a scapegoat? According to Prechter (1999), when social mood changes, people start being more fearful and they express anger through labour disputes, issues of health insurance, etc. The fear and anger seem to have crystallised on Walmart, the symbol of large international companies. Aware that former large retailers, such as Sears of Kmart, have disappeared, Walmart's current CEO seems to have understood that it is time to think, act, and communicate somewhat differently.

The last two letters in the corpus (2015 and 2016) seem to mark a turning point in the company's discourse, and to signal a new start in terms of strategy to address the new challenges. First, quotes or mentions of Sam Walton have disappeared: Unlike his predecessors, today's CEO never met the founder. Instead, the $A B C D$ (Able, Believable, Connected and Dependable) trust model described by Blanchard, Olmstead, \& Lawrence (2013) may have inspired his 2015 letter to associates announcing higher pay. Both his training as an engineer and his credentials make him trustworthy. His goals and values are clear and he does not lie about difficulties. He is 
intent on creating a more engaging working environment for associates; he values and respects them and shows recognition for their vital role; he can be relied on as one of them:

One of the most immediate changes is that we'll raise our starting pay, and we'll provide opportunities for further raises based on performance. For our current associates, we'll start by raising our entry wage to at least $\$ 9$ an hour in April, and, by February of next year, all current associates will earn at least \$10 an hour. [...] Every associate matters. As important as a starting wage is, what's even more important is opportunity, and we'll continue to provide that ladder that any of you can climb. If you work hard, develop new skills and care for others, there should be no limit to what you can do here. That's what makes this place special. I've seen it. I've lived it. And I want nothing more than for every Walmart associate today to feel that same connection to the company that I feel and to have the same opportunities I've had. Let's work together to serve our customers, grow our company, and take care of one another. Thanks for all you do. You really do make the difference.

The future will tell whether the investment in higher wages, in training and careers, and in the company's digital revolution will convince the customers to resume shopping with Walmart, and thus reassure investors. Under the present circumstances, however, the company can neither be complacent nor arrogant, though imparting optimism remains essential:

Although this will be another year of foundational investments, we believe we will soon be growing faster than the retail market. We are a growth company; we just happen to be a large one. The road ahead will not always be easy, but by being customer-focused, hungry, fast and accountable, we will win and have a good time doing it. (AL 2016)

\section{Conclusion}

This brief analysis of Walmart's CEO letters between 2005 and 2016 has brought into relief that their communication strategy to restore reputation and rekindle stakeholder trust is based on engaging with their public, asserting their determination to help the company evolve and change to better meet stakeholders' expectations, while underlining respect for Sam Walton's original values that have made Walmart a success and need to be given a new impetus.

Being a lighthouse seen by all from far away involves challenges; being a behemoth may slow down one's ability to move. As Walmart was celebrating its $50^{\text {th }}$ anniversary in 2012, Columbia University Professor David Hurst (2012) suggested an analogy with an ecosystem, like a forest, considering its evolution "from its small beginning to its large-scale maturity". To him, the analogy could "yield lessons for innovation, growth and organizational renewal". His ecological perspective, when applied to business, underlines points that seem to echo some of the ideas highlighted by CEOs in their letters and some of the decisions they made.

First, such a large organisation should not be considered as a structure, but as movement. When it was born, the company was all movement, until it reached a critical size, with a quasi-monolithic structure. Success may paradoxically be counter-productive, as it makes a company less proactive, too confident in the recipes that used to work, and thus more vulnerable. The journey metaphor introduced in the letters is therefore a means to give the company a new impulse and restore the original pioneering spirit of adventure.

The second point is that change is inevitable. Though Walmart may have chosen to react rather than anticipate in some circumstances, its CEOs have realised that change is the key to a sustainable company, and the word itself has become a leitmotiv in their letters. Hurst (2012) reminds us that "ecosystems need regular disruption to create the open patches necessary for renewal". In his 2016 letter, Walmart's 
CEO announced a 'disruptive' strategy, i.e. an e-commerce revolution to regain the ground lost to Amazon, which points in the right direction. Walmart has decided to put an end to its policy of opening ever more stores; the closure of some stores and the laying off of workers may be disruptive, but, as with a forest fire that renews the forest, "creative destruction" (Schumpeter, 1975 [1942]) seems inevitable. CEOs' insistence on "rethinking", "reinventing", "reimagining" the company to prepare it to be more resilient is also meant to assert their dedication to ensuring it will endure.

Actually, crisis communication, as used by Walmart's CEOs, is a skillful combination of techniques enabling them to impose their thematic choices and to frame issues and events according to circumstances so as to guide stakeholders to make sense of situations. Storytelling is used for building an attractive frame to make people dream of a better world in which the company will be reborn. Bridging past and present by celebrating the company's enduring values and its heroes - the reassuring figure of the late founder, but also the heroic associates ready to help their fellow citizens in case of emergency - is another feature of Walmart CEOs' communication strategy. Metadiscourse and personal accounts aiming at engaging with stakeholders in order to trigger their own engagement and loyalty are also some of the preferred tools in Walmart CEOs' communication toolbox. All the techniques analysed in this paper are meant to reassure the company's stakeholders, and to convince them that the company is able to learn, improve, adapt and endure, and that it will even show others the way forward.

\section{References}

Amernic, J., Craig, R. \& Tourish, D. (2010). Measuring and assessing tone at the top using annual report CEO letters. Edinburgh, Institute of Chartered Accountants of Scotland.

Austin, L., Liu, B. F. \& Jin, Y. (2014). Examining signs of recovery: How senior crisis communicators define organizational crisis recovery. Public Relations Review, 40(5), 844-846.

Barstow, D. (2012, April 21). Vast Mexican bribery case hushed up by Walmart after top-level struggle. The New York Times. Retrieved from https://tinyurl.com/ Barstow2012.

Benoit, W. A. (1995). Accounts, excuses, and apologies: A theory of image restoration strategies. New York, State University of New York Press.

Benoit, W. A. (1997). Image repair discourse and crisis communication. Public Relations Review, 23(3), 177-186.

Bianco, A. (2007, April 30). Walmart's midlife crisis: Declining growth, increasing competition, and not an easy fix in sight. Bloomberg. Retrieved from https://www. bloomberg.com/news/articles/2007-04-29/ wal-marts-midlife-crisis.

Blanchard, K., Olmstead, C. \& Lawrence, M. (2013). Trust works! Four keys to building lasting relationships. New York: Harper Collins Publishers.

Boje, D. M. (2008). Storytelling organization. London: Sage.

Boje, D. M. \& Rosile, G. A. (2008). Specters of Walmart: A critical discourse analysis of stories of Sam Walton's ghost. Critical Discourse Studies, 5(2), 153-179.

Bonini, S., Court, D. \& Marchi, A. (2009). Rebuilding corporate reputations. McKinsey Quarterly. Retrieved from https://tinyurl. com/corporate-reputations2009.

Brennan, N. M., \& Merkl-Davies, D.M. (2013). Accounting narratives and impression management. In L. Jack, J. Davison \& R. Craig (Eds.), The Routledge companion to accounting communication (pp. 109-132). London/New York: Routledge.

Conley, R. (2015). 6 steps to rebuild broken trust. Retrieved from https://leaderchat. org/2015/02/26/6-steps-to-rebuildbroken-trust/.

Coombs, W. T. (2007). Protecting organization reputations during a crisis: The development and application of situational crisis communication theory. Corporate Reputation Review, 10(3), 163-176.

Cunningham, L. (2014). Berkshire beyond buffett: The enduring value of values. New York: Columbia University Press. 
Davis, L. (1999). “Truth to tell: Tell it early, tell it all, tell it yourself": Notes from my White House education. New York: Free Press.

Dragsted, Barbara. (2014). A case study of letters to shareholders in annual reports before, during and after the financial crisis. LSP Journal, 5(2), 84-104.

Fombrun, C. J. \& Van Riel, C. B. M. (2004). Fame and fortune: How successful companies build winning reputations. Upper Saddle River, NJ: Pearson education.

Frandsen, F. \& Johansen, W. (2014). Organizational crisis communication. Thousand Oaks, CA: Sage.

Fuchs-Burnett, T. (2002). Mass public corporate apology. Dispute Resolution Journal, 57(3), 26-32.

Gabriel, Y. (2004). Narratives, stories and texts. In D. Grant, C. Hardy, C. Oswick, \& L. Putnam (Eds.), The Sage handbook of organizational discourse (pp. 62-77). Thousand Oaks, CA: Sage.

Galloway, R. \& Galloway, R. (2005). Why Walmart works and why that makes some people ' $C-R-A-Z-Y$ '. Galloway Productions LLC, Hanover House.

Greenwal, R. (2005). 'Walmart: The high cost of low prices'. Retrieved from https://www. youtube.com/watch?v=RXmnBbUjsPs.

Hurst, D. K. (2012). Why Walmart is like a forest. Strategy+Business, (68). Retrieved from https://www.strategy-business.com/ article/00120.

Hyland, K. (1998). Exploring corporate rhetoric: Metadiscourse in the CEO's letter. Journal of Business Communication, 35(2), 224-245.

Hyland, K. (2005). Metadiscourse: Exploring interaction in writing. London: Continuum.

Jameson, D. A. 2000. Telling the investment story: A narrative analysis of shareholder reports. Journal of Business Communication, 37(1), 7-38.

Kohut, G. F. \& Segars, A. H. (1992). The president's letter to stockholders: An examination of corporate communication strategy. Journal of Business Communication, 29(1), 7-21.
Laskin, A. V. (2009). A descriptive account of the investor relations profession: A national study. Journal of Business Communication, 46(2), 208-233.

Leary, M. R. \& Kowalski, R. M. (1990). Impression management: A literature review and two-component model. Psychological Bulletin, 107(1), 34-47.

Lerbinger, O. (1997). The crisis manager: Facing risk and responsibility. Mahwah, NJ: Erlbaum.

Lischinsky, A. (2011). In times of crisis: a corpus approach to the construction of the global financial crisis in annual reports. Critical Discourse Studies, 8(3), 153-168.

Patel, A. \& Reinsch, L. (2003). Companies can apologize: Corporate apologies and legal liability. Business Communication Quarterly, 66, 17-26.

Prechter, R. R. (1999). The wave principle of human social behavior and the new science of socionomics. Gainesville, GA: New Classics Library.

Resche, C. (2010). «Analyse d'un genre de discours spécialisé: Les lettres annuelles de Warren Buffett aux actionnaires de Berkshire Hathaway et leur spécificité». E-rea. Retrieved from https://erea.revues. org $/ 1365$.

Rutherford, B. A. (2005). Genre analysis of corporate annual report narratives: A corpus linguistics-based approach. Journal of Business Communication, 42(4), 349-378.

Schlenker, B. R. (1980). Impression management: The self-concept, social identity, and interpersonal relations. Monterey: Brooks/ Cole.

Schumpeter, J. A. (1975 [1942]). Capitalism, socialism and democracy. New York: Harper.

Scott, L. (2005, October 23). Twenty first century leadership. Walmart Inc. Retrieved from https://tinyurl.com/Scott2005.

Ulmer, R. R., Sellnow, T. L. \& Seeger, M. W. (2018). Effective crisis communication. Thousand Oaks, CA: Sage. 